Florea : Jurnal Biologi dan Pembelajarannya, 7(1), 2020, 1-6

This is an open access article under the CC-BY-SA license (https://creativecommons.org/licenses/by-sa/4.o/) ISSN 2355-6102(print), ISSN 2502-0404(online)

DOI : 10.25273/florea.v7i1.6525

\title{
PENGARUH MODEL PROJECT BASED LEARNING (PjBL) PADA KONSEP SISTEM KOORDINASI MANUSIA TERHADAP KETERAMPILAN METAKOGNITIF SISWA KELAS XI SMA NEGERI 4 BANJARMASIN
}

\author{
Aulia Mahfuzah ${ }^{1 *}$ dan Siti Ramdiah ${ }^{2)}$ \\ ${ }^{1,2)}$ Program Studi Pendidikan Biologi STKIP PGRI Banjarmasin \\ *email:auliamahfuzah.eff@gmail.com
}

Diterima 12 Maret 2019 disetujui 14 April 2019 diterbitkan 15 Mei 2020

\begin{abstract}
Quality education is needed to support the creation of intelligent people who are able to compete in the era of globalization. However, based on a number of international, national, to regional assessments and facts that are encountered directly in the field, students provide information that student awareness in learning is still lacking. This information shows that the cognitive learning outcomes of students have not been maximized. This study aims to determine the effect of the PjBL model on the metacognitive skills of the XI MIPA grade students of SMA Negeri 4 Banjarmasin. Metacognitive skills can help students develop thinking skills which further influence student learning outcomes. This type of research is a quasi experiment, with a design model known as non equivalent pretest-posttest control group design. Data collection techniques using essay tests. Assessment of metacognitive skills refers to Corebima (2009). The research data were analyzed by one way ANOVA statistical analysis using SPSS version 24 for windows with a significance level of 5\%. The results showed the average value of the experimental class students facilitated by the PjBL model by 85.47 and the control class facilitated by conventional learning by 73.41 with Fcount $=17.616(p=0.000<0.05)$. Thus, it can be concluded that the Project Based Learning model has a significant positive effect on the metacognitive skills of the 11th grade students of Mathematics and Natural Sciences in SMA Negeri 4 Banjarmasin.
\end{abstract}

Keywords: Project Based Learning (PjBL) model, metacognitive skills, human coordination system.

\section{PENDAHULUAN}

Pendidikan yang berkualitas sangat diperlukan untuk mendukung terciptanya manusia yang cerdas serta mampu bersaing di era globalisasi. Hal ini sesuai dengan yang diinginkan oleh tujuan Undangundang No. 20 Tahun 2003. Keberhasilan pendidikan sangat ditentukan oleh baik tidaknya kerja sama antara komponen yang terkait dalam proses pembelajaran. Berangkat dari pernyataan tersebut Rusman (2014) menyatakan, proses pembelajaran dilakukan secara interaktif, inspiratif, menyenangkan, menantang, memotivasi siswa untuk berpartisipasi aktif, serta memberikan ruang yang cukup bagi prakarsa, kreativitas, dan kemandirian sesuai dengan bakat, minat, dan perkembangan fisik serta psikologis siswa.
Gambaran hasil pendidikan pada tingkat internasional menunjukkan data yang sangat memprihatinkan seperti ditunjukkan dari penelitian yang dilakukan oleh Organisation for Economic Cooperation and Development (OECD) rendahnya mutu Pendidikan dapat dilihat dalam laporan studi Program for International Student Assessment (PISA). Hasil tes dan evaluasi PISA 2015 menunjukkan performasiswa-siswi Indonesia masih tergolong rendah, dengan nilai rata-rata skor pencapaian untuk bidang sains berada di peringkat 64 dari 72 negara yang dievaluasi. Menurut Kepala Puspendik Kemendikbud dalam menanggapi hasil Program for International Student Assessment (PISA) 2015, siswa Indonesia bagus dalam mengerjakan soal yang sifatnya hafalan(Kompas, 2016). Namun, selain itu 
belum memberikan informasi yang menggembirakan.

Selanjutnya, terkendala pada skala upaya peningkatan kompetensi guru, yaitu masih rendahnya kualitas guru. Guru besar Universitas Pendidikan Indonesia, Hurriyati (2016) menyatakan kemampuan rata-rata pedagogik berdasarkan data uji kompetensi guru 2015 adalah 56,69\%. Padahal menurutnya, kemampuan pedagogik adalah salah satu kunci keberhasilan dalam mendidik. Berdasarkan Tempo.co (2016) media cetak Kalimantan Selatan, Kepala Dinas Pendidikan Provinsi Kalimantan Selatan menyatakan info yang diperoleh terdapat penurunan kualitas lulusan SMA sebanyak 5\% di tahun 2016.

Berdasarkan fakta yang ditemui langsung di lapangan saat observasi awal dan wawancara tidak terstruktur dengan siswa, memberikan informasi bahwa kesadaran siswa dalam belajar masih kurang. Hal ini dapat terlihat dari sebagian besar siswa mengaku hanya belajar saat ada tugas rumah atau ujian. Tidak jarang, siswa juga mencontek pekerjaan teman atau bahkan menggunakan ponsel secara diamdiam saat ujian berlangsung untuk mencari jawaban melalui akses internet. Informasi tersebut menunjukkan bahwa keterampilan metakognitif siswa belum berkembang dengan baik.

Berdasarkan fakta yang telah diuraikan dari sejumlah penilaian internasional, nasional, dan daerah tentang pembelajaran siswa Indonesia tersebut belum menggembirakan. Hal tersebut tentunya berimbas pada rendahnya kualitas pendidikan yang dihasilkan tidak terlepas dari berbagai faktor diantaranya adalah pengemasan pembelajaran. Proses pembelajaran biologi masih berorientasi pada penyelesaian masalah pada konteks materi, suasana kelas cenderung berpusat pada guru (teacher centered), siswa kurang bisa menalar dan mengaplikasikan ilmu yang dipelajari. Hal tersebut menunjukkan bahwa, pembelajaran yang berlangsung di kelas masih belum mengoptimalkan usaha untuk mengembangkan keterampilan metakognitif.

Keterampilan metakognitif sangat dibutuhkan oleh siswa untuk mengetahui perkembangan hasil belajar yang telah dicapai. Keterampilan metakognitif membantu siswa memantau proses kognitifnya melalui kesadaran proses berpikir, sehingga berpengaruh pada pencapaian hasil belajar yang memuaskan. Alternatif model pembelajaran berbasis proyek sesuai untuk membangun pengetahuan, bekerja sama dalam kelompok, berinteraksi, berkomunikasi dan berkolaborasi serta siswa mampu menciptakan suatu produk yang bermanfaat dalam proses pembelajaran maupun kehidupan sehari-hari.Pembelajaran berbasis proyek ini tidak hanya mengkaji hubungan antara informasi teoritis dan praktik, tetapi juga memotivasi siswa untuk merefleksi apa yang dipelajari dalam sebuah proyek nyata serta dapat meningkatkan kinerja ilmiah siswa. Kemdikbud (2014) mendefinisikan Project Based Learning sebagai model belajar yang menggunakan masalah sebagai langkah awal dalam mengumpulkan dan mengintegrasikan pengetahuan baru berdasarkan pengalamannya dalam beraktifitas secara nyata. PjBL dirancang untuk digunakan pada permasalahan kompleks yang diperlukan siswa dalam melakukan insvestigasi dan memahaminya.

Berdasarkan uraian tersebut, penggunaan model $\mathrm{PjBL}$ adalah salah satu alternatif model pembelajaran yang diduga 
mampu mengembangkan keterampilan metakognitif siswa untuk mencapai tujuan pendidikan yang berharga.Oleh karena itu, peneliti ingin mengkaji lebih jauh melalui sebuah penelitian quasi experiment dengan judul "Pengaruh Model Project Based Learning (PjBL) pada konsep sistem koordinasi manusia terhadap keterampilan metakognitif siswa kelas XI SMA Negeri 4 Banjarmasin".

\section{METODE}

Jenis penelitian ini adalah penelitian quasi experiment, dengan model rancangan yang dikenal dengan nonequivalent pretestposttest control group design. Variabel bebas pada penelitian ini adalah model PjBL dengan variabel terikat yaitu, keterampilan metakognitif. Populasidalampenelitianini adalah siswa SMA Negeri 4 Banjarmasin kelas XI MIPA. Penentuan sampel menggunakan random sampling. Jumlah total sampel pada penelitian ini yaitu 66 siswa dari kelas XI MIPA 1 sebagai kelas eksperimen yang difasilitasi model PjBL, dan kelas XI MIPA 4 kelas kontrol yang difasilitasi dengan pembelajaran konvensional.

Instrumen pengumpulan data yang dimaksud pada penelitian ini terdiri atas instrument untuk mengukur variabel bebas dengan lembar observasi keterlaksanaan model pembelajaran dan instrument pengumpulan data untuk mengukur variabel terikat yaitu, keterampilan metakognitif siswa dengan tes essay. Rubrik penilaian keterampilan metakognitif mengacu pada rubrik yang dikembangkan oleh Corebima (2009) dengan rentang skor untuk setiap soal berkisar 0-7. Pengujian hipotesis dilakukan dengan teknik analisis one way anova menggunakan program SPSS versi24for Windows, dengan taraf signifikansi sebesar 5\%.Sebelumanalisisone way anovadilakukandahulu uji asumsi yang meliputi (1) uji normalitas data dan (2) uji homogenitas.

\section{HASIL DAN PEMBAHASAN}

Berdasarkan penelitian yang telah dilakukan untuk mengukur keterampilan metakognitif yang merupakan kemampuan yang dicapai siswa dari hasil belajar kognitif kelas eksperimen XI MIPA 1 dan kontrol XI MIPA 4 diperoleh nilai pretest dan posttest yang telah disesuaikan dengan rubrik keterampilan metakognitif oleh Corebima (2009) dengan rentang skor 0-7 sebagai acuan penilaian. Ringkasan Hasil Keterampilan Metakognitif Siswa dapat dilihat pada Gambar 1.

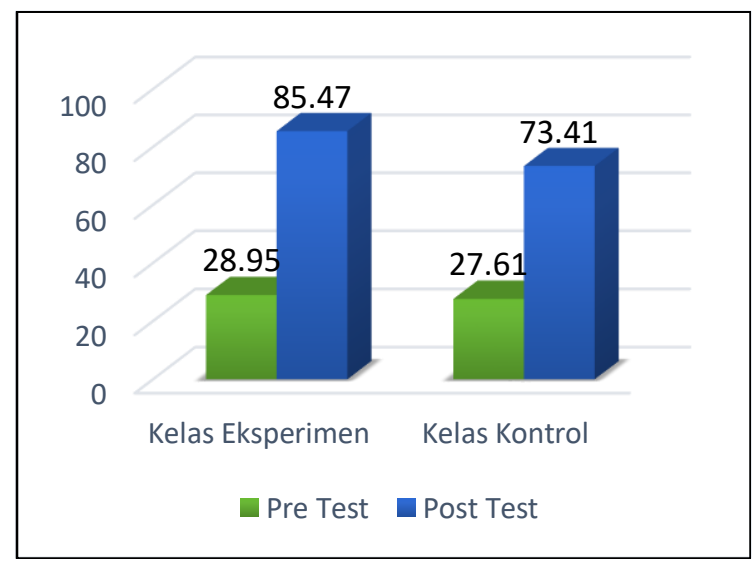

Gambar1. Ringkasan Deskripsi Statistik Hasil Keterampilan Metakognitif Siswa

Hasil belajar tersebut selanjutnya dianalisis menggunakan program statistik untuk mengetahui pengaruhmodel Project Based Learning terhadap keterampilan metakognitif siswa pada kelas yang difasilitasi model Project Based Learningdan kelas dengan pembelajaran konvensional. Secara lengkap hasil analisis statistik disajikan pada Tabel 1. 
Tabel1. Deskripsi Statistik Uji HipotesisHasil Keterampilan Metakognitif

\begin{tabular}{cccccc}
\hline Uji Hipotesis & $\begin{array}{c}\text { Jumlah } \\
\text { Kuadrat }\end{array}$ & $\begin{array}{c}\text { Derajat } \\
\text { Kebebasan }\end{array}$ & $\begin{array}{c}\text { Rata-rata } \\
\text { Kuadrat }\end{array}$ & F & Sig. \\
\hline $\begin{array}{l}\text { Antar } \\
\text { Grup }\end{array}$ & 2396,242 & 1 & 2396,242 & 23,281 & 0,000 \\
\hline $\begin{array}{l}\text { Dalam } \\
\text { Grup }\end{array}$ & 6587,337 & 64 & 102,927 & \\
\hline Total & 8983,579 & 65 & & \\
\hline
\end{tabular}

Berdasarkan hasil analisis data yang telah dilakukan menunjukkan bahwa pembelajaran biologi menggunakan $\mathrm{PjBL}$ berpengaruh terhadapketerampilan metakognitif siswa secara signifikan. Peningkatan dapat dilihat dari hasil tes dengan penilaian keterampilan metakognitif siswa setelah difasilitasi modelPjBL. Hasil analisis menunjukkan bahwa terdapat perbedaan keterampilan metakognitif antara siswa kelas eksperimen dengan kelas kontrol.

Skor rata-rata hasil keterampilan metakognitif siswa kelas eksperimen yang difasilitasi model PjBL sebesar 85,47 dan rata-rata skor siswa kelas kontrol sebesar 73,41. Sehingga secara keseluruhan, keterampilan metakognitif siswa yang difasilitasi dengan model PjBL memperoleh peningkatan keterampilan metakognitif yang lebih tinggi.Hasil analisis tersebut menunjukkan model PjBLlebih unggul dalam meningkatkan keterampilan metakognitif siswa.

Hasil analisis tersebut juga pernah dibuktikan oleh Nadhiroh, dkk (2016) menunjukkan bahwa penggunaan model PjBL dapat meningkatkan keterampilan metakognitif dan hasil belajar biologi siswa melalui perubahan keterampilan siswa dalam bekerja ilmiah. Kemudian, hasil penelitian Widoretno, $\operatorname{dkk}(2016)$ menunjukkan bahwa pembelajaran dengan menggunakan model PjBL dapat memiliki hasil belajar yang lebih tinggi. Hasil penelitian Mayasari (2010), juga menunjukkan bahwa PjBL berpotensi meningkatkan keterampilan metakognitif, karena dapat melibatkan proses berpikir siswa untuk menentukkan strategi belajar sendiri.

Berdasarkan penelitian ini dan informasi sebelumnya maka dapat dikatakan bahwa model PjBL dapat meningkatkan keterampilan metakognitif yang merupakan keterampilan berpikir seseorang untuk menyadari prosesberpikirnya sendiri (Sianturi, 2016). Ardilla, dkk (2010) menambahkan bahwa keterampilan metakognitif dapat membantu mengembangkan kemampuan berpikir siswa yang selanjutnya berpengaruh terhadap hasil belajar siswa.

Berdasarkan hal tersebut keterampilan metakognitif sangat dibutuhkan siswa untuk mengetahui perkembangan hasil belajar yang telah dicapai. Ramdiah (2014) menyatakan "The quality of academic performance can be obtained if the students are able to control their cognitive processes continuously'.Keterampilan metakognitif membantu siswa mengatur proses kognitifnya melalui kesadaran proses berpikir, sehingga berpengaruh terhadap pencapaian hasil belajar yang memuaskan.Pada PjBL hal tersebut terjadi 
saat siswa mengerjakan tugas proyek melalui prosesmembuat tema proyek, merancang proyek, menyusun jadwal, melaksanakan proyek, mempresentasikan hasil proyek, dan mengevaluasi proyek. Tahapan tersebut mendukung siswa untuk menerapkan High Order Thinking Skill (HOTS) dalam proses pembelajaran. Sehingga mampu meningkatkan kualitas pembelajaran sesuai dengan tujuan pendidikan abad 21.

Model PjBL dapat meningkatkan keterampilan metakognitif diduga karena, PjBL mengajak siswa melakukan proyeksi terkait materi pelajaran, pada proses tersebut siswa dilatih bekerjasama dan disiplin mengerjakan proyek. Mandiri dalam kelompok, dan siswa mampu berpendapat untuk bertukar pikiran menunjukkan ide dengan kritis berdasarkan permasalahan. Menurut Ramdiah (2013) hal ini mengungkapkan kesadaran siswa dalam pentingnya belajar dan saling membelajarkan sehingga dapat terbentuk keterampilan metakognitif dalam diri siswa.

Proses PjBL membuat siswa aktif berkomunikasi dalam diskusi dan presentasi proyek yang menghasilkan karya siswa berupa produk sebagai hasil belajar yang direpresentasikan dalam bentuk mading 3D, sehingga mampu merefleksikan kemampuan dalam memahami konsep yang dipelajari. Hal ini teridentifikasi melalui representasi pengetahuan yang telah dipelajari, sejalan dengan yang dijelaskan oleh Kizkapan dan Bektaş (2017), "The students who are skillful in using their metacognitive strategy can understand their strength and weaknesses during their learning. The students who are aware of their own strength and weaknesses are expected to be able to control their own learning (self-regulated learning)"

\section{SIMPULAN}

Berdasarkan uraian yang telah disajikan di atas, maka dapat dinyatakan bahwa model Project Based Learning (PjBL) lebih berpotensi dalam meningkatkan keterampilan metakognitif siswa, dibandingkan dengan pembelajaran konvensional. Hasil penelitian mengungkapkan bahwa terdapat perbedaan keterampilan metakognitif pada kelas kelas eksperimen dan kontrol. Hal tersebut menunjukkan bahwa model PjBL berpengaruh positif terhadap keterampilan metakognitif siswa.

Bagi pemula penerapan model PjBL membutuhkan waktu yang cukup banyak, untuk itu guru perlu sering berlatih dan beradaptasi dengan model pembelajaran ini sehingga dapat lebih mudah mengimplementasikannya pada siswa. Model PjBL direkomendasikan untuk diaplikasikan untuk meningkatkan keterampilan metakognitif sebagai model alternatif pembelajaran biologi pada khususnya, dan diimplementasikan di Sekolah Menengah Atas (SMA) pada umumnya, karena pembelajarannya menerapkanHigh Order Thinking Skill (HOTS) yang diperlukan untuk meningkatkan kualitas pembelajaran abad 21.

\section{DAFTAR PUSTAKA}

Ardila, C. Corebima, A.D. \& Zubaidah, S. (2013). Hubungan Keterampilan Metakognitif Terhadap Hasil Belajar Biologi dan Retensi Siswa Kelas X dengan Penerapan Strategi Permberdayan Berpikir melalui Pertanyaan (PBMP) di SMAN 9 Malang. Malang: Jurusan Biologi, FMIPA, Universitas Negeri Malang. (Online) 
Corebima, A. D. (2009). Metacognitive Skill Measurement Integrated In Achievement Test. State University of Malang. (Online). (http://recsam.edu.my/cosmed/cosmed 09/AbstractsFullPapers2009/Abstract/S cience Parallel PDF/Full Paper/01, diakses 9 September 2017).

Fathurrohman, M. (2015). Model-model Pembelajaran Inovatif: Alternatif Desain Pembelajaran yang Menyenangkan. Yogyakarta: Ar-Ruzz Media Group.

Hurriyati, R. (2016). Kualitas Guru Kita. Bandung: Pikiran Rakyat. (Online). (http://www.pikiran-

rakyat.com/opini/2016/05/04/kualitasguru-kita-368286, diakses 10 September 2017)

Kemdikbud. (2014). Materi pelatihan guru implementasi kurikulum 2013 tahun ajaran 2014/2015: Mata pelajaran IPA SMP/MTs. Jakarta: Kementerian Pendidikan dan Kebudayaan.

Kizkapan, O., Bektaş, O.(2017). The The Effect of Project Based Learning on Seventh Grade Students' Academic Achievement. International Journals of Instruction. 10 (1)

Kompas. (2016). Daya Imajinasi Siswa Lemah. hlm $11 . \quad$ (Online) (http://nasional.kompas.com/read/2016 /12/15/23091361/daya.imajinasi.siswa. lemah, diakses 9 September 2017).

Mayasari, H. (2010). Kajian tentang Pengaruh Model PjBL (Project Based Learning) terhadap Keterampilan Metakognitif Siswa Putra dan Putri Kelas XI SMA Negeri di Malang. Skripsi tidak diterbitkan. Malang: Program Studi Pendidikan Biologi, FMIPA Universitas Negeri Malang.

Nadhiroh, H.A. (2016). Penerapan Model Pembelajaran Project Based Learning (PjBL) untuk Meningkatkan Keterampilan Metakognitif dan Hasil Belajar Biologi Siswa Kelas X4 SMAI Ma'arif Singosari. Skripsi Tidak
Diterbitkan. Malang: Jurusan Biologi, Universitas Negeri Malang. (Online).

Organisation for Economic Cooperation and Development (OECD). (2016). Programme For International Student Assessment (PISA) Result from Pisa 2015: Country Note Indonesia. (Online).

Ramdiah, S. (2013). Pengaruh Strategi Pembelajaran PQ4R terhadap Keterampilan Metakognitif dan Hasil Belajar Biologi Siswa Putra dan Putri Kelas XI SMA di Kota Banjarmasin. Artikel disajikan pada Seminar Nasional X, Pendidikan Biologi FKIP UNS, Semarang, 2013.

Corebima, Duran A. (2014). Learning Strategy Equalizing Students' Achievement, Metacognitive, and Critical Thinking Skills. American Journal of Educational Research, 2014, Vol. 2, No. 8, 577-584.

Rusman. (2014). Model-model Pembelajaran Mengembangkan Profesionalisme Guru: Edisi Kedua. Jakarta: PT Raja Grafindo Persada.

Sianturi, M. J.(2016). Profil Kemampuan Metakognisi Siswa dalam Pembelajaran Biologi pada Kelas XI MIA di SMA Negeri 2 Kota Jambi. Skripsi tidak diterbitkan. Jambi: FKIP Universitas Jambi. (Online).

Tempo.co. (2016). Kualitas Lulusan SMA di Kalimantan Selatan Menurun. (Online). (https://nasional.tempo.co/amp/769907 /kualitas-lulusan-sma-di-kalimantanselatan-menurun, diakses 9 September 2017).

Undang-Undang Republik Indonesia Nomor 20 Tahun 2003 .(2016). Sistem Pendidikan Nasional.

Widoretno, S. Ramli,M. \& Dzaky, Durrotun Adz. (2016). Keterampilan Metakognisi melalui Project Based Learning pada Materi Reproduksi SMA. Proceeding Biology Education Conference. Vol 13 (1) 2016:377-380. 